\title{
La Poesía Afrocubana
}

\author{
INTRODUCCION
}

CUANDO Cuba, amodorrada por siglos de soñoliento coloniaje, 4 despertó a las primeras luces de la ebtullición cultural de fines del siglo XVilI, era ya una sociedad afrohispana. Negros y blancos habían convivido desde los primeros días de la colonización, 1 y juntos habían arreciado la estructura agraria del país. No es de extrañarse, pues, que al comenzar los cubanos blancos a cultivar las letras, no tardaran los cubanos negros en emularles también.

Mas aquéllos eran tiempos de desigualdad y de esclavitud. E1 color de la piel teñía la condición del hombre. El africano valía sólo - para engrosar el chorro de guarapo en el trapiche, o para servir de doméstico en el caserón del blanco. Por tanto, la característica de esta primera etapa de la lírica afrohispana en Cuba es la de negros y mulatos que, negándose a sí mismos, escriben a lo blanco.

Pasa un siglo. Cambian ideas políticas y conceptos sociales, aunque permanecen, en lo económico, condiciones fundamentalmente similares. Sigue el guarapo cristalizándose en ese oro pardo amargo y dulce - que amontonan los centrales. Las dos razas se fusionan cada día más en color y en sentimientos. La república se amulata, el negro se hace doctor, el són se pone de moda: 2 surge la segunda etapa. En ésta, blancos y mulatos, sintiéndose africanos, escriben a lo negro.

La primera etapa, modalidad netamente española, sin otra peculiaridad que la de haber sido escrita en Cuba por individuos de color, nos interesará tan sólo como antecedente histórico y como contraste iluminador a la nueva poesía afrocubana. Es de esta última 
de la que especialmente nos ocuparemos, para ver cómo se enriquece con características que la individualizan, y gana variedades temáticas para el caudal poético de América al enfocar la vida desde el punto de vista del negro. Pero antes de entrar de lleno a discutirla, quiero señalar en qué elementos coincide con la tradición literaria castellana, tanto en España como en Cuba, para mostrar luego los nuevos horizontes descubiertos por esta innovadora poesía.

\section{LO AFROHISPANO EN EL SIGLO DE ORO}

No hay duda de que en el Siglo de Oro existen precedentes a algunas de las características de la presente poesía afrocubana. En primer lugar, la presencia del negro era común en la vida diaria de la península, 3 y como tal aparece en la literatura de esta época. Encontramos al negro en la novela, ya esclavo, como Luis en El celoso extremeño de Cervantes, o libre, como el padrastro del Lazarillo de Tormes. En el teatro aparece, ya hablando ladinamente o ya de manera bozal, mas siempre como personaje bufo y dado a la música, muy semejante al negrito rumbero del llamado teatro típico cubano. 4

En varias comedias y entremeses, con cómicos negros o blancos que imitan a los negros, podemos encontrar ritmos de baile semejantes a los de algunos sones y rumbas. También podemos escoger, aunque de manera inexacta, la reproducción en la escritura de la manera peculiar de pronunciar el español de personas acostumbradas a otros hábitos lingüísticos. Hallamos, por ejemplo, en el Entremés de los negros, 5 de Simón Aguado (1602) el siguiente baile:








$\mathrm{Y}$ así continúa la siguiente estrofa, con idéntica métrica y semejante lenguaje.

Otro ejemplo, siempre con tendencias a lo cómico, y mirado el negro sólo superficialmente y como objeto de bufonadas, es este villancico de Lope, en El capellán de la Virgen: 6

\section{Entrándose las hermosas \\ labradoras de La Sagra. \\ ellos, con disfraces negros, \\ este villancico danzan: \\ E1 hocico de vosa mesé,} he, he, he,

me tiene periro,

de amore venciro.

ay, ay, he, ay, he,

que me motité, que me moriré. 


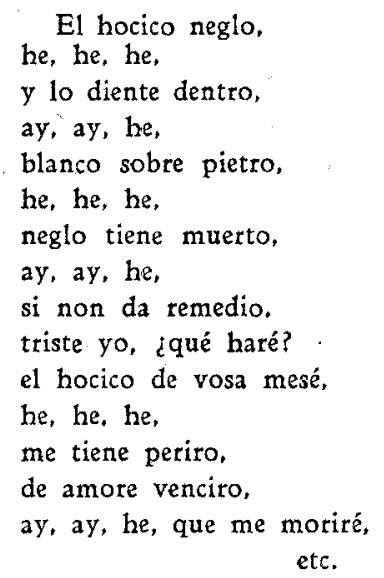

A más de estos cantos y bailes esparcidos por comedias y sainetes, encontramos también el tema negro en la lírica, ya como objeto de zahiriente mofa de parte de Quevedo en "Boda de negros", 7 o tratado con más simpatía en letrillas de Góngora, como por ejemplo, la titulada "Al Nacimiento de Cristo Nuestro Señor", 8 que comienza:

1. ¡Oh, qué vimo, Mangalena!

¡Oh, qué vimo!

2. ¿Dónde, primo?

1. No portalo de Belena.

2. ¿E qué fú?

Entre la hena

muaho sol con mucha raya.

¿Caya, caya!

1. Por en Diosa que no miento.

2. Vamo ayá.

1. Toca instrumento.

2. Elamú, calambú, cambú, elamú. etc.

O esta otra, En la fiesta del Santísimo Sacramento, 9 que principia así:

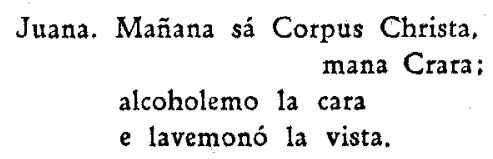




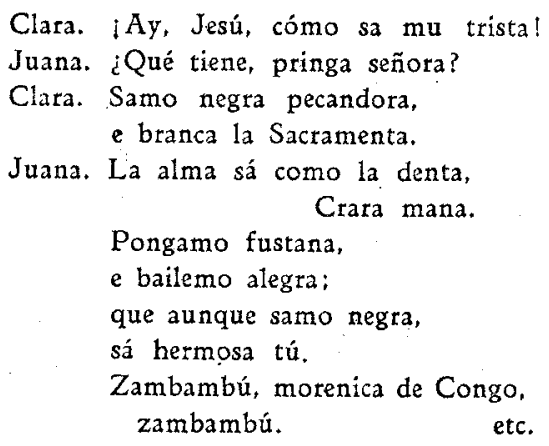

Pudiera continuarse citando ejemplos; no sólo del Siglo de Oro, sino aun con anterioridad (ya Lope de Rueda traía a las tablas al negro como personaje cómico, y el Arcipreste de Talavera hace referencia a "negros, suzios que en verlos es asco e abominación"). 10 Mas sería fuera de proporción a este ensayo aducir más pruebas si con las presentes basta. En los ejemplos citados, siempre visto el negro como tipo cómico, podemos encontrar algunas de las características de la poesía afrocubana - pronunciación desfigurada, palabras de origen africano, ritmo negroide (aunque poco), e íntima unión con la música. Pero sería erróneo afirmar que ya esto es la poesía afrocubana de hoy. Esa poesía afrohispana del Siglo de Oro es superficial, ridícula para ser cómica, sin variedad temática, sin hondas emociones, sin arraigada tradición en el alma del pueblo. Mangalena, Juana y Clara son muñeconas de trapo sin hálito vital, caricaturas tiznadas que nada tienen è común con los completos personajes que nos ofrece la poesía afrocubana. $\mathrm{Ni}$ nada tiene en común la actitud de esos poetas de ayer, que miran al negro desde fuera y desde lejos, como para no tiznarse, con la de estos poetas de hoy, que viven la vida del negro, que juntos con él sufren, lloran, rien, cantan, aman y sueñan!

Tampoco estaría de más hacer notar aquí que, siendo la poesía afrocubana rica en materiales folklóricos, no es de extrañar que se haya asimilado muchas formas de la popular española. Y bien está que así suceda, pues en esta poesía mulata cantan mezcladas Esspaña y Africa. Pero sería decir la verdad a medias si se afirmase que la poesía afrocubana es la poesía popular española con inspiración antillana. También el negro ha contribuído en gran parte a la emoción 
religiosa sin dogma, al sentimiento de la canción popular, al canto de cuna, al baile y al pregón.

\section{LO AFROHISPANO EN CUBA}

Durante este mismo Siglo de Oro en que hemos estado indagando orígenes, Cuba era tan sólo una relegada isla en la ruta de los galeones. Escasos eran sus colonos, y aun algunos de éstos, atraídos por las fabulosas minas del continente, o por el afán de nuevas aventuras, seguían las huellas de Cortés y de Pizarro. Y los que quedaban, aislados en sus dispersos hatos o agrupados en in significantes villas, no tenían ambiente propicio para reflejar aquende el oceáno el dorado fulgor de las letras españolas.

Por eso es notable encontrar que en lo poquísimo que se produjo en esa época, 11 ya se mostraba decididamente la influencia del ambiente afrohispano de la colonia. El poema histórico "Espejo de paciencia", compuesto en 1608 por el canario Silvestre de Balboa (escribano que residía en el entonces caserío de 300 habitantes que hoy es la ciudad de Camagüey), llega a su punto culminante con la valiente acción de un negro cubano. Es éste quien, al ir con los otros vecinos de Manzanillo a rescatar al Obispo Juan de las Cabezas de manos del pirata Gilberto Girón, logra en atrevida pelea dar muerte al forajido francés.

He aquí los versos de Balboa: 12

\footnotetext{
Andaba entre los nuestros diligente

Un etíope digno de alabanza,

Llamado Salvador, negro valiente

De los que tiene Yara en su labranza.

Hijo de Golomón, viejo prudente:

E1 cual armado de machete y lanza

Cuando vido a Gilberto andar brioso,

Arremete contra él cual león furioso.

Don Gilberto que vido al etiope,

Se puso luego a punto de batalla,

$Y$ se encontraron, mas quedó del golpe

Desnudo el negro y el francés con malla.
} 
Mas, a pesar de la superioridad de armas del pirata, el corajudo africano, .. Sin que perdiese un punto en su defensa
Hizose afuera y le apuntó derecho,
Metiéndole la lanza por el pecho.

En estos versos, sin ser afrocubanos, puede notarse un notable progreso sobre los afroespañoles hasta aquí citados. Es cierto que todavía es visto el negro exteriormente, pero no ya como un ente singular y ridículo, sino como parte integrante de la población colonial, objeto de merecida admiración y simpatía. Para no dejar lugar a dudas, el mismo autor dilucida sus sentimientos así:
IOh, Salvador criollo, negro honrado!
Vuele tu fama, y nunca se consuma;
Que,en alabanza de tan buen soldado
Es bien que no se cansen lengua y pluma.
$\mathrm{Y}$ no porque te doy este dictado,
Ningún mordaz entienda ni presuma
Que es afición que tengo en lo que escribo
A un negro esclavo y $\sin$ razón cautivo. 13

Después de este aislado poema, nada hay que citar en las letras cubanas hasta ya bien comenzado el siglo XVIII. Es entonces cuando se empiezan a producir algunas poesías, aunque de escaso mérito, y que no atañen directamente al asunto de este ensayo. 14 La verdad es que Cuba, ahora más ligada a la metrópoli, refleja literariamente el mismo estado de decadencia que carcomía la producción de la península.

No es sino en la segunda mitad del siglo cuando aparecen senales de progreso. La toma de La Habana, en 1762, por los ingleses, produce benéfica influencia en lo económico y da entrada a borbotones de luz en lo intelectual. España, aspirando ella misma aires de reforma y adelanto, envía de Gobernador al Marqués de la Torre, que construye el primer teatro (1776), y luego a Luis de las Casas (1790-96), quien con la cooperación de criollos de la talla de José Agustín Caballero, Arango y Parreño, Zequeira y el doctor Romay, es animador de esa época en que se funda la Sociedad Económica de Amigos del País, aparece el Papel Periódico, se ensancha el comer- 
cio, aumenta la población, se labora en las ciencias, avanzan las artes, y de veras comienzan a florecer por primera vez las letras cubanas.

En esta época de fructífera actividad aparece el primer escritor mulato, el bayamés Manuel del Socorro Rodríguez, 15 brillante autodidacta, quien por 1788 escribe el Elogio de Carlos III, en prosa, y el de los Príncipes de Asturias, en verso, como parte de los ejercicios literarios que se le exigieron en los exámenes que rindió en esa fecha. Poco espués, el progresista monarca le nombraba bibliotecario en Santa Fe de Bogotá. Allí fundó un periódico y continuó su obra literaria como miembro integrante de la vida colombiana.

Por esos mismos años vivió Juana Pastor, parda habanera, de quien sólo se conservan unas décimas y un soneto, escritos por 1815 . 16 Con ella entramos de lleno en el siglo XIX, siglo en que Cuba toma su puesto, al lado de sus hermanas continentales, en la vanguardia de la poesia americana.

Estos son, también, tiempos de enconadas luchas políticas y hondo cisma entre españoles y criollos. En Cuba se intensifica la vigilancia y recrudece el despotismo. La isla es entonces un largo berrugón esclavista en la espalda del trópico. Y el cubano, por lo común liberal y antiesclavista, se pone al lado del negro, mientras el español, por lo general colonial y negrero, se pone bajo las alas de militares dictatoriales enviados por la España antiamericana de Fernando VII y sus sucesores. En estos momentos surgen José María Heredia, el gran bardo prerromántico; José Antonio Saco y Domingo del Monte, publicistas y defensores de la causa liberal, y la pléyade de intelectuales y literatos cuya historia es la historia del pensamiento cubano en su lucha libertaria.

Productos de este ambiente son dos poetas afrocubanos: "Plácido", mulato y libre; Manzano, esclavo y negro. De sus vidas no quiero hablar. Para conocer los sufrimientos del último, baste leer su autobiografía. 17 Para saber el desgraciado fin del otro, baste leer su "Plegaria a Dios", recitada, según se dice, camino al cadalso, por no probadas implicaciones en la conspiración de La Escalera.

A la obra de estos poetas, sin embargo, necesario es que le demos una ojeada, no por su semejanza con la nueva poesía afrocubana, sino por ser exactamente su contraste.

De los versos de Juan Francisco Manzano (1797-1854) se puede decir que son totalmente blancos en la forma. El señor Franco 
dice que el modelo para sus primeros versos, especialmente las letrillas, es el español Arriaza, mas no menciona a Heredia, cuya influencia es clarísima en algunas de las mejores composiciones de Manzano. 18

En cuanto al fondo, cierto es que a veces se inspira en las cosas de Cuba ("La cocuyera", "A la ciudad de Matanzas"), y que su musa es mulata al describir a su Delia como

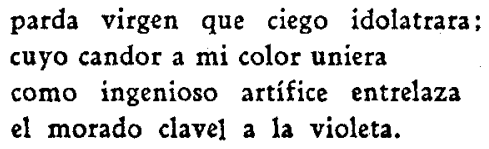

Negro es también el éxtasis -éxtasis de la carne y del coírituque le causa "la métrica cadencia" de la' música, que, al ser producida por las ágiles manos de la parda virgen

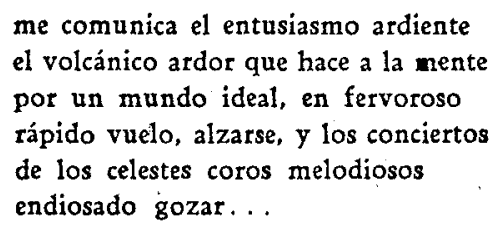

Pero lo más típico de Manzano es su profundo lamento de esclavo maniatado y adolorido, lamento de hombre que lleva en el cuerpo y en el alma las cicatrices de injustas humillaciones.

-Es ese dolor impotente que le hace imaginar, en "Oda a la luna"

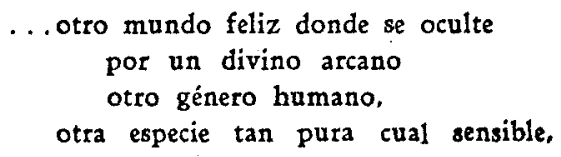

y que le inspiró su soneto "Mis treinta años", cuya traducción al inglés y al francés tanto sirvió a la causa antiesclavista.

De "Plácido" (Gabriel de la Concepción Valdés, 1809-1844), el infortunado hijo de un pardo peluquero y una bailarina burgalesa, mucho se ha escrito, tanto por los indiscutibles méritos de su obra literaria como por la tragedia de su vida misma. $19 \mathrm{Su}$ musa es 
blanca, blanca y a menudo aduladora y mercenaria. De negro tenía muy poco en la sangre y aun menos en sus versos. Su poesía, si a veces da una nota negra, es más por lo tropical que por lo negro; por el clima, más que por la raza. Sin embargo, justo es mencionar que Languasco, al estudiar la poesía romántica en Cuba, 20 hace notar que "la nota sensualista la hallamos sobre todo en algunas poesías de 'Plácido' y señaladamente en el soneto 'A una ingrata'. En esta composición el poeta deja con acento sincero salir libremente de su pluma 'lo que en su alma queda de africano violento.".

Aún hoy se discute si en realidad estuvo él complicado en la conspiración antiesclavista de La Escalera, y se duda si había en él vena sinceramente patriótica o no. La parte política de su vida aquí no me interesa. Sólo le menciono como contraste de los mulatos poetas de hoy, como lo que pudo ser y no fué, ya por razones del ambiente, ya por su misma fibra moral. Muty en particular quiero señalar sus composiciones "Jicotencal" y "Las venturas del trabajo" para que se lean junto con "Los conquistadores" y "Mañana" de Regino Pedroso, en las cuales, como ya ha notado don Fernando Ortiz, se abordan problemas semejantes y se les trata de manera opuesta. 21

Después de estos dos autores, muchos otros poetas de color expresaron en verso sus emociones. Esclavos unos, hombres libres otros. La lista es larga e interesante: Ėchemendía, Betancourt, Rosales, etc. 22 Pero sus composiciones no han pasado más allá de la mediocridad, y existe repetición de la misma nota hasta en algunos de los títulos. Son "Murmurios del Táyaba", "E,cos del Tínima", "Murmurios del Sagua" o "Rumores del Yayabo", títulos más o menos fluviales de poemas más o menos aguados.

TRADICION FOLKLORICA EN CUBA

Hay, finalmente, otro elemento que considerar antes de pasar a estudiar la poesía mulata de hoy. Es el canto folklórico africano trasplantado por el esclavo a su nuevo país. Ahí encontramos el canto de cabildo de la negrada del ingenio, la marcha de comparsa de sus fiestas, o el himno fervoroso a sus dioses, entonados a menudo en ese idioma, mezcla de español y dialectos africanos, que venía a ser como una lingua franca entre los infelices extraídos de distintas re- 
giones por los ávidos buques negreros. Esa poesía popular negra, que coexistía con la décima del campesino blanco y la composición culta del poeta letrado, es la que, viviendo vida de obscuridad durante los siglos XVIII y XIX, ha venido a brotar redimida en lo más puro de la música y el verso afrocubanos de hoy. 23 Gracias a la paciente labor de jóvenes eruditos, continuadores de los estudios fundamentales de don Fernando Ortiz, todo esto se investiga ahora concienzudamente. José Antonio Portuondo acopia datos sobre las "tumbas" negras en Santiago. Guirao, en su Orbita de la poesía afrocubana, ha recogido y publicado, bajo el epígrafe de "Antecedentes folklóricos", varias composiciones anónimas de ambos siglos, y en estos momentos prepara una Antología de cuentos negros. Quiero citar sólo tres de las composiciones recogiclas por Guirao.

La primera, un canto de cabildo, anónima del XVIII, comienza así:

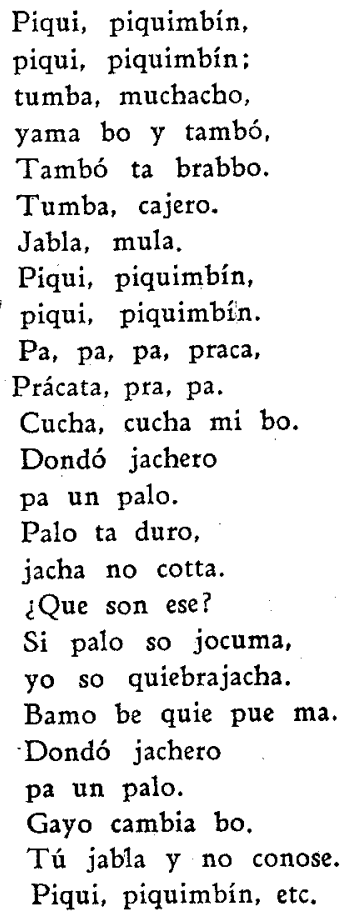


Este canto de cabildo ya muestra el ritmo agreste, la desaforada predilección por la onomatopeya, y la alegría desbordada del cantor.

La segunda composición, igualmente anónima del siglo XVIII, es el siguiente canto de comparsa:

\section{"Ta Juliá"}

- Ma Rosario ta mala.

(iCángala lagontó!)

-A be qué cosa tiene.

( Cángala lagontó!)

-Tiene barriga y doló.

(iCángala lagontó!)

-Etá embarasá.

(¿Cángala lagontó!)

-Culebra l'asutta.

(¿Cángala lagontó!)

- ¿Qué diablo son ese?, pregunta e mayorá.

Mira diente d'animá.

mira forma ne roccá,

mira sojo d'ese nimá,

¿candela ne parese?

¿Qué nimá son ese

que ne parese majá?

Ta Juliá mimo ba matá.

(iBáquini ba di ba yo!)

- ¿Qué nimá son ese?

(iBáquini ba di ba yo!)

-Yo coje guataca.

(¡Báquini ba di ba yo!)

-Yo coje la pala.

(iBäquini ba di ba yo!)

- Tierra co l'asaó.

(iBáquini ba di ba yo!)

- Ma Rosario ta buena.

(iBáquini ba di ba yo!)

-Mañana ba trabajá.

(¡Báquini ba di ba yo!)

-Grasia ta Juliá.

(iBáquini ba di ba yol)

-Fué quié la mató.

(¡Cángala lagontó!) 
Esta composición, que pudiera considerarse como antecesora de negrísimos poemas como el "Sensemayá" de Guillén, intensifica aún más la resonancia oxitónica de los versos y trae el tema ofídico de que hablaré después.

La última de estas citas, "Mamá Iné", ha sido fechada por Guirao en 1868. Es esta Mamá Iné, dicho sea de paso, la que no sólo ha dado vena a una popularísima rumba que, junto con "El Manisero", rompió los límites insulares de la música afrocubana para hacerse continental y cosmopolita, sino que ha venido a transformarse, como Papá Montero, en personaje simbólico, abuela de la María Belén Chacón y los Quintín Barahona, especie de Eiva y Maria del mulato cubano. Oigamos la composición:



Con estos antecedentes históricos, definidos ahora, podemos entrar de lleno a estudiar la verdadera poesía afrocubana de hoy.

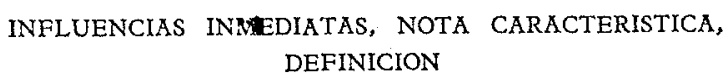

Para que los poetas afrocubanos encontraran el rico filón nativo, fué necesario un estímulo de afuera. Cierto que ya habían ron- 
dado el tema negro, aunque situados en medio del modernismo, José Manuel Poveda con su "Grito abuelo", y Felipe Pichardo Moya con "La comparsa". Pero la moda de lo negro, como otras muchas modas literarias, nos vino importada de Europa.

Por 1912, con el viaje de León Frobenius al Africa, se cimienta la pasión por el negrismo como años antes se había admirado el japonesismo mallarmeano. "Se remonta esta influencia", dice Guirao, "a los orígenes nebulosos, imprecisos, del cubismo. Apollinaire es uno de los admiradores. Cendrars y Morand, viajeros por Tombuctú; Modigliani, Picasso, Braque, Derain, Vlaminck, Guillaume, Soupault, y, más tarde, Goll, desde París, inician el 'negrismo'." 24 La guerra mundial, con la venida de soldados coloniales, aumenta la curiosidad por el negro y da pábulo al interés por las cosas prietas. Se aplaude a Josefina Baker y se baila el jazz afroamericano.

Los Estados Unidos, con su vasta población negra, rica desde antaño en tradición musical y literaria, cuajaba lo negro en obras, ya de poetas de color como Langston Hughes, o de blancos interesados en lo negro, como Eugene O'Neill, cuyo Emperador Jones, estrenado en 1920, lo traduce R. Baeza, en 1929, con la nota "Quizás si algún día hubiera de llevarse a nuestra escena, lo más acertado sería intentar una adaptación criolla convirtiendo a Jones en un negro antillano de habla española". 25

En la América hispana, el puertorriqueño Luis Palés Matos comienza a escribir poemas de asunto negro en 1926, aunque su negro, según Margot Arce, "es un negro teórico, abstracto, que Palés no ha visto", 26 y muchos de sus versos, según Ortiz, "son realmente blancos, no teniendo otros caracteres mulatos que la plétora de vocablos africanoides..." También labra en la misma cantera un poeta uruguayo, Ildefonso Pereda Valdés. Es entonces -ya 1928 - cuando con la publicación de la "Bailadora de Rumba", de Guirao, "La Rumba", de Tallet, y dos poemas de Carpentier, "se vincula a la llamada nueva sensibilidad la tradición poética popular del afrocubano". 27

La moda negrista, sin embargo, tuvo vida muy distinta en Europa a la que ha llevado en Cuba. Allá eran arios sorprendidos quienes veían las cosas africanas con la momentánea curiosidad del turista que mira, admira y anota en su diario de viajero apresurado. Estos cansados artistas europeos sólo buscaban una paleta- 
da de pigmento con que colorear sus desteñidas inspiraciones; algo que fuera nuevo, distinto, aunque advenedizo, transitorio, fugaz. $Y$ se ponen a observar tambores, flechas, lanzas, y olvidan mirar al alma del negro y ver en ella reflejos de la suya propia. El arte europeo sólo ansiaba sentir su tonicidad poniéndose en contacto con el ignoto arte del salvaje. Y nada más.

En Cuba, por el contrario, lo negro tenía raigambre de cuatro siglos. El cubano blanco no veía en el negro al africano con collares de dientes de cocodrilo, sino a otro cubano, tan cubano como él, ciudadano de la misma república que juntos habían forjado a fuerza de machetazos. La moda europea vino a dar oportunidad al cubano negro de reconocerse a sí mismo, y al cubano blanco de mirarlo con ojos de entendimiento, de comprensión. Ambas razas se fusionan en lo artístico, como ya lo habían hecho en lo económico y político, para producir esta modalidad literaria.

Con tal aportación, ahora podía unirse el cubano a la literatura indigenista de las Américas. Sin gauchos que cantar, sin indios que defender, ahí tenía al negro, material vivo, rico en matices folklóricos. $\mathrm{Y}$ poseyendo esa actitud de franca simpatía, los poetas afrocubanos pudieron cavar hondo y encontrar al negro real y verdadero, y verlo por dentro, sentirlo en toda su complejidad, no como muñecones cómicos pintados de hollín, ni como piezas de museo con raros ornamentos de curiosos diseños, sino como hombres: hombres de piel prieta y labios gruesos, pero desbordantes de vida y emoción.

Ahora bien, ¿en qué consiste esta poesía negra? ¿Es tan sólo una forma amanerada de decir las cosas en jerga africanoide? No. La "Balada del Güije", de Guillén, y la "Elegía de María Belén Chacón”, de Ballagas, escritas en perfecto castellano, son, sin embargo, negrísimas. Consiste esta poesía - escrita dialectalmente o no- en ver las cosas desde el punto de vista del negro, estar profundamente ligada a la música, los ritmos y los sentires del afrocubano.

Ese dialectalismo negro, creo yo, no presenta dificultades de orden fonético al lector avezado a las formas populares del español hablado en distintas regiones del mundo hispánico. $28 \mathrm{Y}$ los pocos términos de origen africano empleados, pueden encontrarse con fa- 
cilidad en el excelente Glosario de afronegrismos de don Fernando Ortiz.

Ocasiones habrá, sin embargo, en que ni hallará el significado de ciertas frases ni falta tampoco hará, pues han sido escritas más bien para ser sentidas que para ser entendidas. Es esta poesía riquisima de onomatopeyas que atrevidamente imitan cualquier sonido musical, desde el cosquilleo rumboso de las maracas hasta la carcajada estridente del cornetín. Excelentes ejemplos son los siguientes de "La Rumba", de Tallet, "gran obertura de la lírica cubana de los motivos negroides", como la llama Ortiz al analizarla: 29

Zumba, mamá, la rumba y tambó, mabimba, mabomba, bomba y bombó,

que representa el redoble de los tambores.

Chaqui, chaqui, chaqui, charaquí, chaqui, chaqui, chaqui, charaquí,

que recuerdan el chasquido de las maracas, y Paca, paca, paca, paca, pam, pam, pam,

instrumento el exhausto bongosero.

que reproduce los últimos ecos que saca a su

De Tallet también, en su "Quintín Barahona", son estas cornetinadas :

¡Sopla, resopla, resopla!

iTarariiiii!

IResopla, requetesopla!

¡Tararaaá!

Guillén, en "Secuestro de la mujer de Antonio", oye de los timbales un

$$
\begin{aligned}
& \text { repique, pique, repique, } \\
& \text { repique, repique, pique, } \\
& \text { pique, repique, repique, } \\
& \text { ipo! }
\end{aligned}
$$

Y Ballagas, en "Nombres negros en el són", pone a bailar las parejas

al tiqui-ti de las claves. 
Pero, si se recuerda, en el canto de cabildo antes citado teniamos ya audaces onomatopeyas tales como:

Piqui, piquimbin, piqui, piquimbín pa, pa, pa, praca prácata, pra, pa.

A veces sucede que este anhelo de resonancias vacía a ciertas palabras de su significado, si es que lo tuvieron, para dejarles tan sólo el sonido. $\mathrm{Y}$ este rítmico cantar sin pensamiento - cerrazón completa de la mente para seguir en éxtasis el compás- es lo que se llama jitanjáfora. 30 ¿Qué importa que las palabras "sóngoro" $y$ "cosongo" tengan o no significado en lo siguiente?

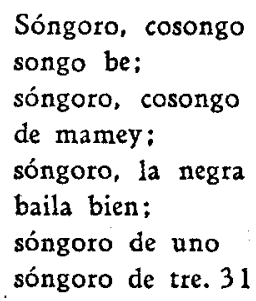

Lo importante es el ritmo, la cadencia musical, aunque no representen esas palabras idea alguna.

Del "Pregón", también de Guillén, recogemos las siguientes jitanjáforas :



Y del "Canto negro" del mismo poeta :

Yambambó, yambambé!

Tamba, tamba, tamba, tamba, Itamba del negro que tumba: tumba del negro, caramba, caramba, que el negro tumba: yamba, yambó, yambambé! 
De la observación de esas onomatopeyas y jitanjáforas puede deducirse hasta qué grado ha influído la música africana en' esta clase de versos. Esta música africana "en el ritmo quebrado y en la síncopa de la rumba, y en los acentós metronómicos de la clave es donde asoma más vigorosamente". $32 \mathrm{Y}$ el verso afrocubano se ajusta a ese ritmo musical que lo inspira como ceñida bata blanca al cuerpo de una rumbera. De ahí su tendencia binaria, su resonancia oxitónica de bongó, y como consecuencia, la aparición a veces del verso acentual y la variedad estrófica de algunos poemas. Por eso, los que hemos visto en las Antillas a la mulata cocinera caminando hacia el mercado con un descoyuntamiento rítmico en la cintura, o al negrito pregonando sus turrones de coco con una rumba en los pies, bien podemos seguir el paso del negro de alpargatas rotas cuando leemos:

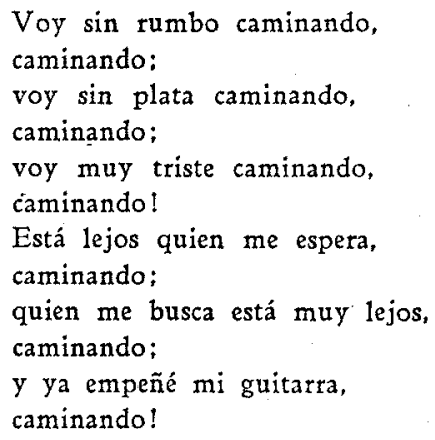

(De "Caminando")

Igualmente, no podemos leer sin ponerle música, de ésas escondidas en nuestra subconsciencia, cualquiera de estas estrofas:

Yo quiero un nobio dotó, curujey, curujey; pa bé si el nobio me cura, curujey, curujey:

lo que tengo en la sintura. 


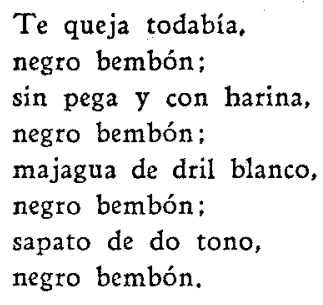

(De "Negro Bembón")

Tanto tren con tu cueppo,

tanto tren;

tanto tren con tu boca,

tanto tren:

tanto tren con tu sojo,

tanto tren;

(De "Mulata")

Sácala de la cosina,

sácala de la cosina,

Mamá Iné.

Mamá Iné, tú bien lo sabe,

Mamá Iné, yo bien lo sé;

Mamá Iné, te llama nieto,

Mamá Iné.

$$
\text { (De "Ayé me dijeron negro") }
$$

Estos ejemplos, del más acabado de los músicos del verso mulato, son realmente "motivos de són". Y $\tan$ es así, que varios compositores, incluyendo a Roldán, han musicalizado estos poemitas de Guillén.

\section{ALGUNOS CONCEPTOS DIFERENCIALES DEL NEGRO}

Pasemos ahora al orden de las ideas. Hay notables diferencias entre los sentires del af́ricano y los del europeo. Su idealización de la belleza, por ejemplo, es distinta de la del blanco; su concepto del amor es más biológico y natural; su misma psiquis, primitiva y sencilla, muestra la infantilidad de la raza en manifiesta predilección por los colores brillantes, perenne atracción por la música, alegría desbordada de vivir, ancestral terror por heredadas supers- 
ticiones. $\mathrm{Y}$ todo esto, claro está, le hace también menos ridículamente romántico, desposeído de refinada hipocresía, más apegado a la tierra. Pero, al generalizar, estoy pintando el tipo del bon sawvage como progenitor de los afrocubanos de hoy. Más atinado es, con el documento poético en la mano, hallar éstas y quizás otras diferencias raciales.

Innecesario es decir que para el africano to bello es lo "negro. "BBlanco amarillo!" contesta el afrocubano al que le grita "inegro bembón!" y pálida y descolorida debe de parecerle la piel del criollo comparada con la brillantez achocolatada o negroazulosa de su piel. Ya Manzano comparaba su color con morados claveles y violetas. Portuondo habla de "tu dura carne abrasada" y "tu carne prieta y sabrosa", Guillén "de carnes puras y negras", y Ballagas

$$
\begin{aligned}
& \text { de carne tostada al fuego, de carne quemada al sol, } \\
& \text { de tersa carne templada al fuego como un bongó. }
\end{aligned}
$$

$$
\text { (De "Negros nombres en el són") }
$$

Los labios, gruesos; la sonrisa, amplia; los dientes, blancos y fuertes como los de un tiburón. He ahí el ideal negro. Dice Portuondo:

sólo tendrás de marfil, blancos y lindos, los dientes.

(De "Lance de Juruminga")

Y Gómez Kemp:

dientes de masa de coco en prieta piel de mulata, ¿Risa que se prende al péndulo rojo y blanco de tu bata!

(De "Fuego con fuego")

Guillén patéticamente ve la "sonrisa de labios gordos" del muerto chiquitín. Esténger imagina el éxtasis cimarrón con

... un candor de coco

entre sus labios morados!

(De "Leyenda del cimarrón") 
Y Ballagas adormece a un ebónico infante con :

$$
\begin{aligned}
& \text { drómite mi nengre } \\
& \text { mi nengre bonito } \\
& \text { [Diente de merengue } \\
& \text { bemba de caimito! }
\end{aligned}
$$

$$
\text { (De "Para dormir a un negro") }
$$

Pero donde más se distancian los gustos raciales es en la figura de la hembra. Esbeltez, cuello de cisne, talle de palmera, para el blanco; ancas potentes, ágiles hombros $\mathrm{y}$, sobre todo, nalgas : grandes, pulposas, contráctiles nalgas prietas, para el negro. Don Fernando Ortiz, que todo lo nota, ha escrito ya documentados párrafos sobre esta última peculiaridad, remontándose en sus investigaciones etnográficas e históricas a la esteatopigia de las mujeres etiópicas y a los frescos sepulcrales de las reinas egipcias. 33 Citar ejemplos sería pedantesco. Léase cualquier poesía afrocubana, y se encontrará lo que digo en todo su vigor descriptivo. $Y$ si se quiere saber el por qué, véase a una pareja de rumberos y no será necesario explicar más. Para el negro, y con razón, la hembra es un compuesto de hombros y nalgas unidos por un ombligo en perenne movimiento envolvente:

$$
\begin{aligned}
& \text { El ombligo es vórtice, } \\
& \text { el vientre es ciclón. } \\
& \text { iLas anchas caderas } \\
& \text { y su pañolón! } 34
\end{aligned}
$$

Esto, necesariamente, me trae a discutir el concepto negro del amor. Para ellos, amor es reproducción. $Y$ no se les tilde, llevados por un puritanismo exagerado, de inmorales por la sensualidad y sexualidad de su existir. Creerlos inmorales porque en su composición hay más de carne que de espíritu, es llamar inmoral al pájaro que se reproduce libremente en el bosque, llevado del más fundamental de los instintos de todo organismo viviente. La influencia telúrica de sus llanos incendiados de sol los ha hecho como son, apasionados sin refinamientos, desbordantes del vigor progénico de los trópicos. No me molesta leer, por ejemplo: 
Abren sus anchas narices ventanas de par en par

a un panorama sensual. 35

O este otro:

\section{Crucero de tus caderas}

en siete mares de rumba;

iba grumete el deseo

sobre tu grupa ardorosa,

y en alto, de gallardete,

con la rabia de un mordisco,

sobre tu bemba sabrosa,

toda la sangre de un beso. 36

No me escandalizan estas composiciones, porque ellas recogen la manera natural, biológica, de quienes sólo así saben expresar ideas que los blancos hemos aprendido a sutilizar y a disfrazar en eufemismos más o menos evidentes.

\section{TROPOS}

En cuanto a símiles y metáforas, ya se habrá notado, de pasada, la recurrente mención a frutas tropicales - dientes de coco, labios de caimito, senos de nísperos. Igual stucede con los instrumentos musicales - bongó, clave, maraca, güiro, botija, guitarra. Son perennes las alusiones y comparaciones con ellos, y a veces, como las maracas de Guillén, en $W$ est Indies Ltd., y el atabal en su "Canción del Bongó", se personifican para convertirse en símbolos, de anhelos de independencia económica las primeras, de igualdad racial el segundo. Ejemplo, que por lo sencillo, rítmico e imaginativo cito, es la composición de Gómez Kemp titulada:

\footnotetext{
"Rumba de Tumba y Dale"

Tumba y dale, dale y tumba, tumba y dale que la rumba se crucificó en las claves.
} 




Otra imagen omnipresente en la poesía negra es la serpiente culebra, majá. La explicación se remonta a los orígenes totémicos de su religión. Sus cantos para matar colebras -modernos como el de Guillén, o antiguos como los anónimos citados por Guirao en sus "Antecedentes folklóricos" y Ballagas en su Antología- dan esa impresión de total africanismo religioso. Igual sucede con "La 
comparsa del majá", de Arozarena, equivalente a las procesiones blancas de los católicos. Pero ya en esta composición se nota la tendencia a unir la imagen del reptil con las ofídicas contorsiones de la rumba. "Un majá de sabrosura que te muedde las caderas", dice Arozarena.

Guirao ve que:

Las serpientes de sus brazos van soltando las cuentas de un collar de jabón.

(De "Bailadora de rumba")

y Portuondo:

$$
\begin{aligned}
& \text {...en tus piernas } \\
& \text { se enredaron las culebras } \\
& \text { de las miradas negras... }
\end{aligned}
$$

(De "Mari Sabel")

Pudiera notarse, en fin, la profunda atracción del negro por lo rojo. Recuérdese la camisa colorada de Papá Montero, la "cobbata colorá" del "Firulítico", el pañuelo rojo de la "Bailadora de rumba", de Guirao, o del "Són con punta", de Gómez Kemp. Aun en "Liturgia", de Carpentier,

$$
\begin{gathered}
\text { El gayo murió } \\
\text { lyamba ó! } \\
\text { en el rojo altar } \\
\text { del gran Obatalá. }
\end{gathered}
$$

Para acabar estas observaciones sobre tropos, veamos cómo hasta la luna se emplea mulatamente, șin las cursilerías románticas del blanco. Gómez Kemp la hace negra y la emborracha de rumba. 37 Ballagas también la hace rumbera en "Comparsa habanera". Y para Guillén, es la luna "muerta y blanca" contraste a la "carne prieta y viva" de Papá Montero. 38 Por eso el frío disco plateado le sirve para ponerlo de funerario adorno en la cama del rumboso Baldomero, en una estrofa que es modelo de la más pura y sencilla poesía popular: 
Hoy amaneció la luna

en el patio de mi casa:

de filo cayó en la tierra

y alli se quedó clavada.

¡Los muchachos la cogieron

para lavarle la cara,

y yo la traje esta noche

y te la puse de almohada!

(De "Velorio de Papá Montero")

\section{VARIEDAD TEMATICA}

Finalmente, ¿es ésta una poesía de lira monocorde? ¿Es rumba y canela "na má"? Los poetas de esta escuela han sabido no dejarse cautivar ni por lo dialéctico y jocoso ni por lo simplemente descriptivo. Han buscado también expresar lo acrisolado por el sentimiento $y$ verterlo en moldes de gran poesia; hacer inteligible al indoamericano y al hispano su sentir antillano. De ahí la extensa gama de emociones $y$ abundancia de motivos que encontramos como asunto a la modalidad mulata de la poesía cubana.

Lo cómico está fuertemente representado por los chistosísimos monólogos "Un despojo" y "Los novios" (ambos éxitos rotundos en la escena al ser recitados por la Cosme), el "Coloquio", de Rafael Esténger, y varios poemitas de Guillén, tales como "Me bendo caro", "Mulata" y "Tú no sabe inglé". Este lo cito ya que interesará más al lector anglosajón:

Con tanto inglé que tú sabía

Bito Manué,

con tanto inglé, no sabe ahora

desí: ye.

La americana te buca

y tú le tiene que huí;

tu inglé era de etrai guan,

de etrai guan y guan-tu-tri.

Bito Manué, tú no sabe inglé,

tú no sabe inglé,

tú no sabe inglé.

No te enamore ma nunca,

Bito Manué,

si no sabe inglé,

si no sabe inglé. 
La poesía simplemente descriptiva tiene un magnífico ejemplo en "Rumba", de Tallet. Todo el drama mínimo que entraña la danza está allí captado como por lente cinematográfico. "Esstampa de San Lázaro", de Guirao, es un cuadro animado que se nos entra por todos los sentidos. Y las fantásticas imágenes que ve la feraz imaginación de la madre negra, movida por atávico terror, quedan impresas en la "balada del güije" de Guillén con dantesca maestría.

Con tema musical abundan numerosos motivos de són y letras de rumba de Ballagas, Guillén, Hernández Catá, Portuondo, Gómez Kemp, Radillo, etc. En grupos aparte dentro de lo musical, pudiéramos poner los pregones (Guillén, Ballagas) y las canciones de cuna, o nanas, entre las cuales ha escogido Eusebia Cosme para sus recitales la "Canción de cuna de la negra esclava", de Regino Boti, por su alto valor dramático y limpio sentido trágico.

En la frontera entre lo musical y lo religioso están "La canción del jigüe", de Teófilo Radillo, y el "Sensemaya", de Guillén. Expresando fases del culto negro, hallamos la sencilla y primitiva "Liturgia", de Carpentier. A este grupo religioso pertenece también la "Leyenda del cimarrón", de Esténger, excelente poetización de un hecho representativo y desgraciadamente muy común en la historia de la esclavitud.

La conmovedora "Balada del güije", mezcla de lacerado dolor materno y terror supersticioso, es modelo del grupo de poemas de emociones acrisoladas por la tragedia. Ahí caben también "Velorio de Papá Montero", "Elegía de María Belén Chacón" y la patética "Canción de cuna de la negra esclava".

El espiritu. de algunas de estas composiciones ha hecho a lo negro desembocar necesariamente en lo social. Aquí se aclara el verso para obscurecerse el tema. Negros nubarrones de descontento se hacinan presagiando rojizas tempestades. Recuérdese que muchos de estos poemas fueron escritos en los años de mediatización que siguieron al machadato. De ahí la nota de derrotismo de Guillén en West Indies Ltd. para rehacerse después (1937) en Cantos para soldados y sones para turistas. Tallet hace historia, historia de blancos y negros, cuando su Quintín Barahona, "negro cubano na má", dice : 


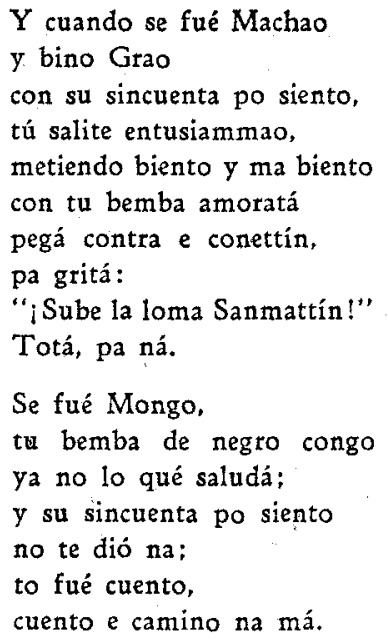

Ballagas, sintiendo la desilusión del negro más allá del momento político, contrasta en "Actitud" la situación social del afrocubano:

A la hora de l'apuro "iQue benga el negro!"

A la hora de l'ahogo, "ISálbame, hemmano!"

A la hora 'e la pelea, "QQue benga el negro!"

A la hora 'e lo mameye,

"iCorre, moreno!"...

$Y$ el negro duda y sonríe.

Ta bien...

El negro sonríe y duda, ¡Ta bien!

El negro sonríe y mira, El negro calla y medita

$Y$ se arma de precaución.

A la hora de la lija, quitate, negro...

En el satón de lo blanco, pa fuera, negro.

A la hora de la fietta, záfate, negro, no sea relambío,

¿Date tu lugá! 
Y Regino Pedroso, poeta de los temas sociales desde 1926, y con Guillén el más sincero en la queja y más avanzado en el objetivo, con la filosofia del asiático y el arrojo del africano, da esta clarinada:

\section{"Hermano negro"}

Negro, hermano negro, tú estás en mí: ihabla!

Negro, hermano negro, yo estoy en ti: icanta!

Tu voz está en mi voz, tu angustia está en mi voz, tu sangre está en mi voz... ITambién yo soy tu raza!

iNegro, hermano negro, el más fuerte, el más triste, el más lleno de cantos y de lágrimas!

Tú tienes el canto. porque la selva te dió en las noches sus ritmos bárbaros; tú tienes el llanto, porque te dieron los grandes ríos caudal de lágrimas.

iNegro, hermano negro!

¡Negro, más por el hambre que por la raza!

Tú fuiste libre sobre la tierra, como las bestias, como los átboles. como tus ríos, como tus soles... Fué carcajada bajo los cielos tu cara ancha. $Y$ fuiste esclavo; sentiste el látigo encender tu carne de humana cólera, $y$ ardiendo en llanto, cantabas.

INegro, hermano negro! itan fuerte en el dolor que al llorar cantas! 
Pata sus goces

el rico hace de ti un juguete,

y en París, y en New York, y en Madrid, y en la Habana, igual que bibelots

se fabrican negros de paja para la exportación:

hay hombres que te pagan con hambre la risa;

trafican con tu sudor:

comercian con tu dolor,

Y tú ríes, te entregas y danzas.

¿Tú amaste alguna vez?

¡Ah, si tú amas, tu carne es bárbara!

¿Gritaste alguna vez?

¡Ah, si tú gritas, tu voz es bárbara!

¿Viviste alguna vez?

¡A , si tú vives, tu raza es bárbara!

Negro, hermano negro,

más hermano en el ansia que en la raza.

Negro en Haiti, negro en Jamaica, negro en New York, negro en la Habana

- dolor que en vitrinas negras vende la explotación-. escucha allá, en Scottsboro, en Scottsboro, en Scottsboro...

Da al mundo, con tu angustia rebelde,

tu humana voz...

Iy apaga un poco tus maracas!...

Idéntica nota da Guillén en "Sabás". Pero no es necesario continuar. Como se ve, por la puerta de lo social ha salido lo negro a lo universal. Esto ya está fuera de los límites estrictos de lo afrocubano.

\section{CONCLUSION}

Para que nada le faltara, esta modalidad poética ha tenido investigadores y críticos en Ortiz, Marinello y Guirao; ha sido llevada como poesía viva a escenarios continentales por Eusebia Cosme; y ha llegado hasta Europa. En España Unamuno la admira, García Lorca la siente. En Alemania Vossler confiesa su interés por ella. $\mathrm{Ha}$ vivido en diez años vida de escuela hecha. 
"El recodo negro" parece haber cerrado su ciclo, pero ha dejado tras sí brillantes realizaciones. Las puertas del arte han quedado abiertas de par para aceptar la contribución del hombre de piel obscura. Las comparsas habaneras han sido revividas. La música popular muestra decididamente la crecida influencia africana. El cuento negro ha aparecido ya. En las caldeadas costas del Mar Caribe ha inflamado un reguero de anhelos el estremecimiento poético de la conciencia afrocubana!

JosÉ JUAN Arrom, Yale University.

\section{NOTAS}

1 "Con los blancos de Diego Velázquez, y acaso antes, en los clandestinos cabotajes a la rapiña, ya vinieron negros". F. Ortiz, Los factores humanos de la cubanidad, p. 7.

2 No sólo en la música popular se generaliza lo negro, sino que ritmos tomados de su liturgia son elevados a categoría sinfónica por Roldán, García Caturla, etc. Véase A. Salazạr: "E1 movimiento africanista en la música de arte cubana" y J. L. Vidaurreta: "Ensayo sobre la música cubana", ambos en la revista Estudios Afrocubanos, vol. II, núm. 1 (1938).

3 No estoy de acuerdo con Pereda Valdés cuando en su ensayo "Contribución al estudio del tema del negro en la literatura castellana hasta fines de la Edad de Oro", p. 8, dice: "¿Pudo conocerse en el siglo XVI el tema negro en España a no ser por su proyección americana? De Africa a América, y de América a Europa: tal es la trayectoria del negro". Creo que fué a la inversa. Había negros en España y Portugal antes de 1492, y en los prime. ros permisos para introducir negros en Santo Domingo se exigía que éstos fueran nacidos entre cristianos e instruidos en la fe católica.

4 Como ejemplo de notable similitud con el dicharachero y conversador negrito rumbero, véase el entremés $E l$ negrito hablador y sin color anda la niña, de Quiñones de Benavente (N. B, A. E., vol, XVIII, pp. 605-607). En particular nótese, a más de su parecida pronunciaciótín a la de un negro santiaguero, su amot a la música cuando dice:

E1 culazón me cosquiya,

quitaliya $\mathrm{O}$ h, cómo suena!

No cé que liabo ce tiene

ezte modo de instulmenta:

cómo le tengo infición

$y$ tora el arma me yeva. 
No es raro, pues, que el amo de Gaspar, en el Entremés de los negros que cito en mi próximo párrafo, diga de su esclavo: "FFuego de Dios en él! Si va a la plaza, ha de ser con la guitarra en la mano; si llega a comprar escarola, ha de ser haciendo la chacona".

5 En N. B. A. E., vol. XVII, pp. 231-235. 65-66.

6 Cita de J. Robles Pazos en Lope de Vega, Cancionero teatral, pp.

7 Para dar una idea del tratamiento de este asunto en manos de Quevedo, baste citar las dos primeras estrofas:

$\mathrm{Vi}$, debe de haber tres días,

En las gradas de San Pedro,

Una tenebrosa boda,

Porque era toda de negros.

Parecía matrimonio

Concertado en el infierno:

Negro esposo y negra esposa,

$Y$ negro acompañamiento. 253.

8 Góngora: Romances $y$ letrillas, ed. de P. Henriquez Ureña, p.

9 Ibid., p. 235.

10 En El Corvacho, cap. 18, titulado "Cómo es muy engañoso el amor de la mujer".

11 C. M. Tielles, en su artículo "Los poetas cubanos de los siglos XVII y XVIII agrupados por regiones" (Revista Cubana, vol. II, pp. 173-180), deja ver que, a excepción de lo que escribiera Cortés mientras fuera alcalde de Santiago, del poema de Balboa a que voy a referirme, y los seis sonetos preliminares que a su principio se insertaron, no se conoce ninguna otra producción poética hasta más de un siglo después.

12 El poema completo ha sido conservado en la Historia de la isla y catedral de Cuba, de Morel de Santa Cruz. Estos versos aparecen en la p. 170 , ed. de la Academia de la Historia de Cuba, 1929.

13 Ibid., p. 171.

14 Estos son los tiempos de José Surí, José Rodríguez (Capacho), y otros poetas citados sólo como curiosidades en el desarrollo histórico de la poesía en Cuba. Paralelamente coexisten en esta época cantos de cabildo, de comparsa, etc., netamente negros, de los cuales hablaré más adelante.

15 Ver F. Calcagno: Diccionatio biográfico cubano, pp. 546-49. 
16 C. M. Trelles: "Bibliografía de autores de la raza de color, de Cuba", en Cuba Contemporánea, vol. XLIII, núm. 169, pp. 30-78.

17 J. L. Franco: Autobiografia, cartas y versos de Juan Fco. Manzano, Habana, 1937.

18 La influencia herediana es clara en el metro, el estilo y aun el pensamiento poético. La composición de Manzano titulada "La Música", comienza :
Detén la diestra mano encantadora angelical mujer, átzala en tanto que entusiasmado tu bondad implora tu más débil cantor. ISí, Delia hermosa!
Torne a su ser el alma que extasiada, incierta discurría...

que recuerda demasiado literalmente frases completas de la "Oda al Niágara" de Heredia.

Igual sucede con estos otros versos de la misma composición:

$$
\begin{aligned}
& \text { lleno de desamor el pecho helado } \\
& \text { contemplarte podré.. } \\
& \text { Tus manos, iay! tus manos } \\
& \text { Oh, magia! cuyo efecto poderoso } \\
& \text { me comunica el entusiasmo ardiente. }
\end{aligned}
$$

Quien se interese, puede continuar haciendo igual comparación entre la "Oda a la luna", de Manzano, y "Al Cometa de 1825", de Heredia.

19 Véase C. A. Cervantes: "Bibliografía placidiana", en Revista Cubana, vol. III, núms. 22-24 (1937), pp. 155-186. Esta completa 1a "Bibliografía placidiana" de Trelles, publicada en Cuba y América, julio, 1904.

20 B. Languasco: La poesía romántica cubana, p. 151.

21 F. Ortiz: "Más acerca de la poesía mulata", Rev. Bim. Cub., vol. XXXVII, núm. 1, p. 26.

22 Véase el artículo de Trelles ya mencionado. También el libro de F. Calcagno: Poetas de color, y el artículo de R. Guirao: "Poetas negros y mestizos de la época esclavista", en la revista semanal Bohemia, Habana, agosto 26,1934 .

23 Pero puede apreciarse la notable influencia que lo negro ejercía ya en la música popular en la valiosa colección de Guatachas cubanas... desde las más antiguas hasta las más modernas, $2^{a}$ ed., Habana, 1882.

24 R. Guirao: Orbita de la poesia afrocubana, p. xiv.

25 Revista de Occidente, vol. XXIV, 1929. 
26 Cita de Ortiz, "Más acerca de la poesía mulata", Rev. Bim. Cub., vol. XXXVII, núm. 1, p. 24.

27 Guirao: Orbita de la poesía afrocubana, p. 52.

28 Los más comunes cambios morfológicos del lenguaje del negro cubano son:

(a) seseo: corasón < corazón; cosina < cocina; gosá < gozar.

(b) yeísmo: gayo < gallo; cabayero < caballero; eya $<$ ella.

(c) omisión de la $\mathrm{s}$ (o z) en sílaba certada:

etreya < estrella; Iné < Inés; narí < nariz; conoco < conozco.

(d) omisión de la $d$ en las terminaciones -ado, -ada:

Machao < Machado; colorá < colorada.

(e) pérdida de las consonantes finales $l, t, d$ : totá < total; Bitto Manué < Víctor Manuel; beddá < verdad.

(f) asimilación de consonantes y a veces duplicación: cobbata $<$ corbata; cuppa $<$ culpa; connettín < cornetín.

(g) metátesis de las líquidas $l$ y $r$ : nolmá < normal.

(h) aféresis y apócope: tá < está; pa ná < para nada.

$Y$ se habrá notado que el metacismo pasa también a la escritura: bo < voz.

29 F. Ortiz: "Más acerca de la poesía mulata", Rev. Bim. Cub., vol. XXXVII, núm. 1, p. 26.

30 El inventor de esta palabra es Mariano Brull, y el teorizador, Alfonso Reyes. Véase G. de la Torre: "Literatura de color", en Rev. Bim. Cub., vol. XXXVIII, núm. 1, p. 10. Se pueden encontrar escritos sobre este asunto en Libro, de Buenos Aires, vol. 1, 1929, y en Revista de Auance, de la Habana.

31 Guillén: "Si tú supiera"...

32 E. Sánchez Fuentes: "Influencia de los ritmos africanos en nuestro cancionero", Anales de la Academia Nacional de Artes y Letras, vol. XI (1927) p. 151.

33 F. Ortiz: "Los últimos versos mulatos", Rev. Bim. Cub., vol. XXV, núm. 3, pp. 326-29.

34 Ballagas: "Rumba".

35 Ballagas: "Comparsa habanera".

36 Portuondo: "Lance de Juruminga".

37 "Luna negra".

38 Ya un mito afrocubano explica que cuando los hombres no estaban divididos aún en razas, uno de éstos subió al sol por una escala de luz y, al quemarse la piel, se tornó negro. Otro subió a la luna y allí se hizo blanco. 
